\title{
Uji Aerasi Microbubble dalam Menentukan Kualitas Air, Nilai Nutrition Value Coefficient (NVC), Faktor Kondisi (K) dan Performa pada Budidaya Nila Merah (Oreocrhomis Sp.)
}

\author{
Eny Heriyati ${ }^{1}$, Rustadi ${ }^{2}$, Alim Isnansetyo ${ }^{3}$, dan Bambang Triyatmo ${ }^{4}$ \\ ${ }^{1}$ Sekolah Tinggi Pertanian Kutai Timur, Jl. Soekarno Hatta no.1. Sangata, Kutai Timur, \\ Kalimantan Timur \\ 2,3,4 Fakultas Pertanian Universitas Gadjah Mada, JL. Flora, Bulaksumur, Kec. Depok, \\ Kabupaten Sleman, Daerah Istimewa Yogyakarta \\ 1.Email: enyheriyati@stiperkutim.ac.id \\ 2 Email: rustadi@ugm.ac.id \\ ${ }^{3}$ Email: isnansetyo@ugm.ac.id \\ ${ }^{4}$ Email: bambang_triyatmo@ugm.ac.id
}

\begin{abstract}
This study aims to examine the use of microbubble aeration on water quality parameters, performance, NVC values and water condition factors. Fish measuring 12 $\pm 3 \mathrm{~g}$, as many as 50 fish kept for 3 months with microbubble aeration, conventional aeration and non-aerated treatment in the recirculation system. The parameters analyzed in this study showed the DO value of microbubble aeration was higher and lasted until the end of the study compared to conventional aeration and control ( $p$ $<0.05$ ), as well as water temperature. Other water quality parameters are not affected by aeration treatment, and still show normal values for tilapia cultivation, except that ammonia in all treatments shows values that exceed SNI standards. The influence of the stable $D O$ value produced by microbubble aeration affects the performance of tilapia, which is able to increase the size of fish weight per tail and increase fish biomass $268 \%$ from the control and $32.5 \%$ higher than conventional aeration. In this study the condition factor and NVC values of all treatments showed relatively the same values. The conclusion of this study is that, although the condition factor and NVC values are not influenced by aeration treatment, microbubble aeration can increase DO, growth and biomass of fish.
\end{abstract}

Keywords: Microbubble aeration, DO, Performance, K value, NVC

\section{ABSTRAK}

Penelitian ini betujuan untuk menguji penggunaan aerasi microbubble pada parameter kualitas air, performa, nilai NVC dan factor kondisi perairan. Ikan berukuran $12 \pm 3 \mathrm{~g}$, sebanyak 50 ekor dipelihara selama 3 bulan dengan perlakuan aerasi micobubble, aerasi konvensional dan non aerasi dalam system resirkulasi. Parameter yang dianalisa dalam penelitian ini menunjukkan nilai DO aerasi microbubble lebih tinggi dan tetap bertahan lama sampai akhir penelitian dibandingkan aerasi konvensional dan control $(\mathrm{p}<0,05)$, demikian juga dengan suhu air. Parameter kualitas air lainnya tidak dipengaruhi oleh perlakuan aerasi, dan masih menunjukkan nilai yang normal untuk budidaya nila, kecuali ammonia pada semua perlakuan menunjukkan nilai yang melebihi standar SNI. Pengaruh stabilnya nilai DO yang dihasilkan oleh aerasi microbubble berpengaruh pada performa nila, yang mampu meningkatkan ukuran bobot ikan tiap ekor dan meningkatkan biomasa ikan $268 \%$ dari kontrol dan 32,5\% lebih tinggi aerasi konvensional. Dalam penelitian ini nilai factor kondisi dan NVC dari semua perlakuan menunjukkan nilai yang relative sama. Kesimpulan dari penelitian ini adalah, meskipun nilai kondisi dan NVC tidak dipengaruhi perlakuan aerasi, namun aerasi microbubble mampu meningkatkan DO, pertumbuhan dan biomasa ikan.

Kata kunci: Aaerasi microbubble, DO, Performa, Nilai K, NVC 
http://ojs.stiperkutim.ac.id/index.php/jpt https://doi.org/10.36084/jpt..v8i1.232
Jurnal Pertanian Terpadu 8(1): 27-41, Juni 2020

ISSN 2549-7383 (online) ISSN 2354-7251 (print)

\section{Pendahuluan}

Produksi ikan budidaya mengalami penurunan dari tahun 2015 sampai dengan 2016 sebesar 8,6 \% (FAO, 2018), namun demikian nila sebagai salah satu ikan budidaya ekonomis penting di seluruh dunia produksinya telah meningkat empat kali lipat selama dekade terakhir dan Indonesia pada tahun 2017 produksinya mencapai 1,15 juta ton atau naik sebesar 3,6\% dari tahun 2016 (KKP 2017).

Untuk memaksimalkan produk akibat permintaan yang meningkat, budidaya ikan nila semakin diperluas dengan dilakukan kepadatan tinggi dan dalam volume air yang terbatas atau dilakukan secara intensif. Meskipun terjadi peningkatan produksi, namun bukan berarti tidak terdapat permasalah yang harus dihadapi terutama masalah keterbatasan lahan, dan kualitas air, yang secara langsung memberikan dampak negatif terhadap penurunan produktivitas sumberdaya alam. Penurunan mulai terlihat pada perairan umum yang menunjukkan penurunan debit air secara terus menerus sehingga perlu ada strategi bagaimana mencukupi kebutuhan pangan ditengah permasalahan keterbatasan sumberdaya air dan lahan. Oleh karena itu sistem budidaya secara intensif perlu dilakukan untuk mengatasi masalah ketersediaan lahan dan air.

Faktor kualitas air dijadikan sebagai indikator dalam keberhasilan atau kegagalan dalam kegiatan akuakultur. Lingkungan budidaya yang baik bagi kehidupan ikan akan berpengaruh positif terhadap tingkat pertumbuhan. Pertumbuhan ikan sangat dipengaruhi oleh tingkat metabolisme ikan yang cepat, dan hal ini berhubungan dengan oksigen yang tersedia di perairan. Berkurangnya tingkat DO akan berakibat pada nafsu makan, konversi pakan, pertumbuhan dan kesehatan ikan budidaya. Dalam mengatasi berkurangnya tingkat kelarutan oksigen, sebuah inovasi teknologi terbaru telah diciptakan yaitu microbubble generator (MBG). MBG merupakan teknologi yang berfungsi sebagai penghasil oksigen terlarut dalam air dengan ukuran gelembung mikro yang lebih kecil dari aerator biasa (Deendarlianto, et al., 2015). Aerator ini juga mampu meningkatkan massa dan panjang ikan hasil budidaya dan memperpendek masa panen produksi perikanan budidaya, dan mampu meningkatkan beberapa parameter kualitas air (Budhijanto et al., 2016). Beberapa penelitian melaporkan bahwa gelembung mikro mempercepat pertumbuhan pada budidaya ikan (Matsuo et al., 2001; Ohnari et al., 2002).

Sistem budidaya secara intensif selain sering terjadi masalah degradasi yaitu kualitas air yang bermasalah, juga terjadi kerentanan terhadap wabah penyakit, dan merupakan faktor yang signifikan tidak bisa hilang. Faktor penyakit mengindikasikan status kesehatan ikan, dan suatu metode untuk melihat normal tidaknya tingkat kesehatan ikan dapat dilakukan dengan menghitung nilai NVC, yaitu apabila bernilai kurang atau sama dengan 1,7 menunjukkan bahwa kualitas perairan tersebut sudah tercemar sehingga ikan 
tidak memenuhi syarat kesehatan dan mempunyai nilai gizi yang buruk (Lucky,1977). Selain nilai NVC perlu juga untuk melihat nilai faKtor kondisi (nilai K), yaitu kajian hubungan panjang berat (Okgerman, 2005) untuk melihat pola pertumbuhan ikan budidaya dan status kesehatannya. Lebih lanjut Frose dan Torres (2006) menambahkan bahwa nilai faktor kondisi dapat menggambarkan keadaan fisiologis dan morfologis spesies berkenaan misalnya bentuk tubuh, kandungan lemak dan tingkat pertumbuhan. Di perairan umum, faktor kondisi juga dapat mengambarkan ketersediaan makanan di alam atau keseimbangan antara predator dan mangsa.

Sampai saat ini penelitian mengenai pengaruh aerasi microbubble untuk melihat status kesehatan ikan berdasarkan nilai NVC dan nilai $\mathrm{K}$ belum pernah dilakukan. Oleh karena itu penelitian ini bertujuan untuk mengetahui pengaruh aerasi menggunakan microbubble dibandingkan dengan aerasi konvensional dalam menentukan parameter kualitas air, performa ikan, NVC dan faktor kondisi media yang dilakukan rekayasa dengan aerasi tersebut.

\section{$2 \quad$ Metode Penelitian}

\section{Waktu dan Alat Penelitian}

Penelitian ini dilakukan pada bulan April hingga Juli 2018. Pelaksanaan penelitian di Kolam dan Laboratorium Departemen Perikanan Fakultas Pertanian Universitas Gadjah Mada. Analisis parameter kualitas air dilakukan di Laboratorium Fakultas Geografi Jurusan Teknik Lingkungan UGM. Performa ikan dilakukan di laboratorium akuakultur perikanan UGM.

Bahan dan alat yang digunakan dapat dilihat pada tabel 1.

Tabel 1. Bahan dan alat yang digunakan dalam penelitian

\begin{tabular}{clll}
\hline No & Bahan/Alat & spesifikasi & kegunaan \\
\hline 1. & Aerator & MBG dan Blower & Meningkatkan DO \\
2. & Bak ikan & Volume $1 \mathrm{~m}^{3}$ & Wadah pemeliharaan \\
3. & Nila merah & Berat rata-rata $13,6 \mathrm{~g}$ & Bahan uji \\
4. & Pakan komersial & HI-PRO-VITE 781(Protein 32\%) & pakan ikan \\
5. & WQC & YSI 556 MPS & Mengukur DO, suhu dan \\
& & & pH \\
6. & Aquades & & Larutan pengencer \\
7. & Bahan-bahan kimia & $\mathrm{H}^{2} \mathrm{SO}_{4}, \mathrm{NaOH}$, indicator pp, & $\mathrm{CO}_{2}$, dan alkalinitas \\
& & indikator methyl orange (MO) & \\
8. & Spektrofotometer & metode fenat & Mengukur amonia \\
9. & Timbangan & ketelitian $0,5 \mathrm{~g}$ & Mengukur bobot ikan \\
10. & Penggaris & Ketelitian $1 \mathrm{~mm}$ & Mengukur panjang ikan \\
\hline
\end{tabular}

\section{Rancangan Penelitian}

Penelitian ini menguji kemampuan aerator microbubbles dibandingkan dengan menggunakan sistem aerator konvensional dalam menentukan status kualitas air, nilai NVC, factor kondisi (K), dan performa nila merah dengan sistem resirkulasi. Penelitian didesain dalam rancangan acak kelompok, dengan tiga ulangan perlakuan, yaitu: 
A 1-3: Pemeliharaan nila tanpa aerasi

B 1-3: Pemeliharaan nila menggunakan aerator konvensional

C 1-3: Pemeliharaan nila menggunakan MBG

Variabel yang diukur selama penelitian meliputi uji sintasan, laju pertumbuhan spesifik, rasio konversi pakan (FCR), kualitas air yang meliputi suhu, oksigen terlarut/DO, $\mathrm{CO}_{2}, \mathrm{pH}$, alkalinitas, dan amoniak $\left(\mathrm{NH}_{3}\right)$. Selain itu juga dilakukan analisa factor kondisi $(\mathrm{K})$ dan nilai NVC.

\section{Persiapan Bak}

Persiapan yang dilakukan pada penelitian awal adalah pembuatan sistem resirkulasi, dan pemasangan microbubble generator (MBG) pada 3 bak, pemasangan aerator pada 3 bak, dan 3 bak lainnya tidak diberi aerasi. Bak yang telah dibersihkan diisi dengan air yang berasal dari air bor, dan dilakukan pengukuran kualitas air pada sumber air. Sistem resirkulasi dan pompa untuk MBG dijalankan, dengan debit air 2,5 L/menit. Masing-masing bak diisi dengan air sebanyak kurang lebih $900 \mathrm{~L}$. Volume dan debit air dipertahankan dalam kondisi yang sama dari awal penelitian.

\section{Pemeliharaan ikan}

Ikan yang digunakan berasal dari BBI Cangkringan, Sleman, Yogyakarta. Benih yang ditebar pada tiap bak sebanyak 50 ekor dengan ukuran $12 \pm 3$ gr/ekor. Sebelum ditebar ikan dipelihara pada kolam selama satu minggu, selanjutnya secara acak ikan ditebar dalam bak pemeliharaan dan diaklimatisasi selama satu minggu. Selama proses pemeliharaan tahap pertama pakan yang diberikan berupa pakan komersial dengan merek dagang HI-PRO-VITE 781 dengan kandungan protein $31-33 \%$, lemak 3-5\%, serat 4-6\%, kadar abu $10-13 \%$, dan kadar air 11-13\%. Pemberian pakan dilakukan secara adlibitum sebanyak 3 kali sehari.

\section{Pengukuran Kualitas Air.}

Parameter kualitas air dilakukan secara berkala setiap 2 minggu sekali. Parameter kualitas air $\mathrm{pH}$, suhu air dan oksigen terlarut diukur menggunakan Water Quality Checker (WQC). Analisa $\mathrm{CO}_{2}$, dan alkalinitas diukur dengan cara titrasi, sedangkan amonia dilakukan di Fakultas Geografi, Laboratorium Jurusan Teknik Lingkungan UGM.

\section{Pengukuran Performa, NVC dan nilai K}

Pengukuran panjang dan berat ikan dilakukan secara sampling setiap dua minggu sekali sebanyak 25 ekor (50\%), kecuali saat akhir penelitian semua ikan diukur panjang dan bobotnya. Perhitungan NVC (nutrition value coeficient) sebagai bioindikator dan nilai factor kondisi (K) dilakukan pada akhir penelitian.

\section{Laju Sintasan (Survival Rate)}


ISSN 2354-7251 (print)

Rumus yang digunakan untuk mengetahui laju sintasan menurut Ronald et al. (2014)

adalah sebagai berikut:

$$
\mathrm{SR}=\frac{\mathrm{Nt}}{\mathrm{No}} \times 100 \%
$$

Keterangan:

$$
\begin{aligned}
& \mathrm{SR}=\text { Laju } \\
& \mathrm{Nt} \\
& \begin{array}{ll}
\mathrm{No} & =\text { Jumlahan }(\%) \\
\mathrm{No} & \text { Jumlah ikan akhir pemeliharaan }
\end{array}
\end{aligned}
$$

\section{Pertumbuhan Mutlak}

Pertumbuhan mutlak menurut Asma et al. (2016), dihitung dengan rumus:

$$
\begin{aligned}
& \mathrm{W}=\mathrm{Wt}-\mathrm{Wo} \\
& \text { Keterangan : } \\
& \mathrm{W}=\text { Pertumbuhan berat mutlak }(\mathrm{g}) \\
& \mathrm{Wt}=\text { Berat ikan akhir }(\mathrm{g}) \\
& \text { Wo }=\text { Berat ikan awal }(\mathrm{g})
\end{aligned}
$$

\section{Laju Pertumbuhan Spesifik}

Rumus yang digunakan untuk mengukur pertumbuhan spesifik menurut menurut Ronald et al. (2014), adalah sebagai berikut:

$$
\mathrm{SGR}=\frac{\text { In Wt-In Wo }}{\mathrm{t}} \times 100 \%
$$

\section{Keterangan:}

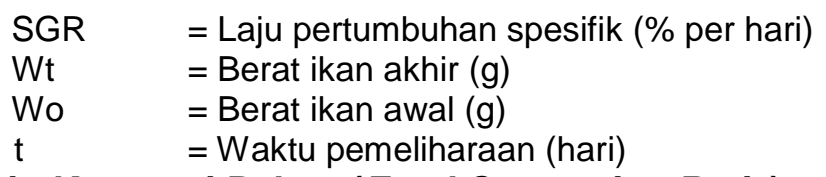

\section{Rasio Konversi Pakan (Feed Convertion Ratio)}

Konversi pakan atau Feed Convertion Ratio (FCR) menurut Ronald et al. (2014) dapat dihitung dengan rumus:

$$
\mathrm{FCR}=\frac{\mathrm{F}}{((\mathrm{Wt}+\mathrm{D})-\mathrm{Wo})}
$$

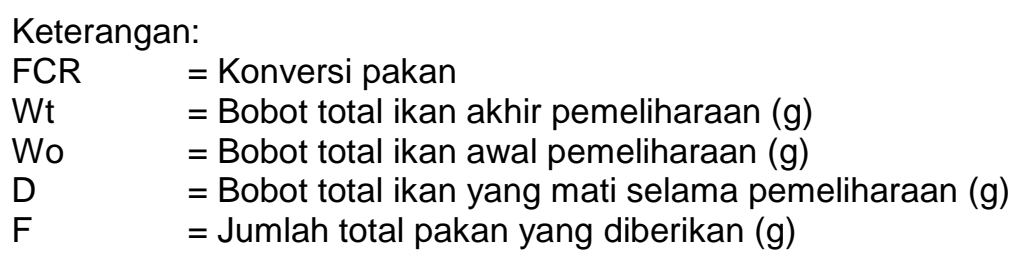

NVC

Nilai NVC dihitung dengan rumus formula Furton (Lucky, 1977):

$$
\mathrm{NVC}=\frac{\text { Berat } \times 100}{(\text { panjang })^{3}}
$$

\section{Faktor K}


Faktor kondisi dihitung dengan menggunakan sistem metrik berdasarkan hubungan panjang bobot ikan sampel. Jika pertambahan bobot seimbang dengan pertambahan panjang maka pertumbuhan ikan bersifat isometrik sehingga persamaan untuk menghitung faktor kondisi menurut (Effendie 2002) :

$$
K=\frac{10^{5} w}{L^{3}}
$$

Apabila pertumbuhan bersifat allometrik yakni pertambahan panjang dan pertambahan bobot tidak seimbang, maka persamaannya menjadi :

$$
K=\frac{W}{a L^{b}}
$$

Jika didapatkan $b=3$, maka pertambahan bobot seimbang dengan pertambahan panjang (isometrik). Bila didapatkan $\mathrm{b}<3$, maka pertambahan panjang lebih cepat dibandingkan dengan pertambahan bobot (allometrik negatif). Jika $b>3$, maka pertambahan bobot lebih cepat dibandingkan pertambahan panjangnya (allometrik positif).

\section{Analisa statistik}

Data yang diperoleh diolah dengan menggunakan one way anova SPSS versi 25, dengan uji lanjut duncan selang kepercayaan $95 \%$. Selanjutnya hasil yang diperoleh disajikan dalam bentuk grafik dan tabel.

\section{Hasil dan Pembahasan}

\section{Kualitas Air}

Hasil pengukuran kualitas air dapat dilihat pada tabel 2 berikut ini :

Tabel 2. Kualitas air pada peraluan kontrol (A), aerasi blower (B) dan aerator microbubble (C)

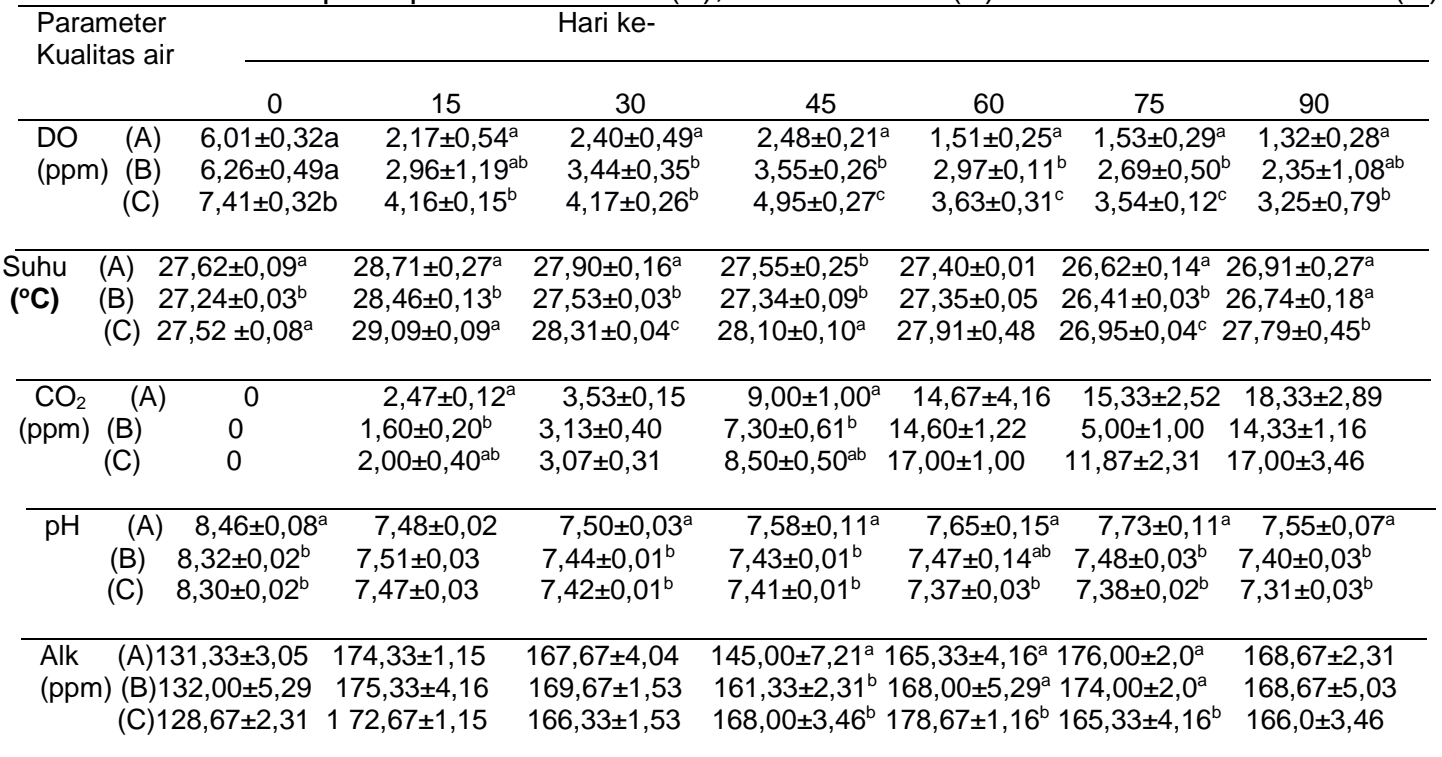

Keterangan : Rerata pada kolom yang sama diikuti oleh huruf yang berbeda menunjukan ada beda nyata pada tingkat kepercayaan $95 \%$

Tabel 2 menunjukkan perbedaan nilai DO selama penelitian yang berfluktuatif, namun aerator microbubble menghasilkan nilai yang selalu lebih besar yaitu selalu diatas 3 ppm, sedang DO aerator konvensional kurang dari 3 ppm. Nilai rerata pada perlakuan 
menggunakan aerator keduanya menunjukkan nilai yang lebih tinggi $\quad(p<0.05)$ dibandingkan dengan perlakuan non aerasi (kontrol) yaitu kurang dari 2 ppm, yang seluruhnya dioperasikan dalam sistem resirkulasi.

Suhu pada semua perlakuan cenderung berfluktuatif, mengalami peningkatan pada minggu ke-2 $\left(28-29^{\circ} \mathrm{C}\right)$ dan pada minggu ke-4 hingga minggu ke-10 suhu mengalami kecenderungan yang terus menurun $\left(26^{\circ} \mathrm{C}\right)$, dan sedikit naik kembali pada minggu ke-12 pada semua perlakuan $\left(26-27^{\circ} \mathrm{C}\right)$. Perlakuan kontrol tidak berbeda nyata $(p>0,05)$ dengan perlakuan aerator konvensional, tetapi berbeda nyata dengan perlakuan aerasi microbubble $(\mathrm{p}<0,05)$.

Nilai $\mathrm{pH}$ selama penelitian hasilnya berfluktuatif, namun antar perlakuan aerasi menunjukkan tidak berbeda nyata $(7,31-7.40)(p>0,05)$, dan berbeda $(p<0,05)$ dengan nilai pH kontrol yang cenderung lebih tinggi $(7,55)$ dari perlakuan aerasi. Namun demikin kisaran nilai dalam penelitian masih bagus yaitu berkisar antara 7,3-8,4

Nilai $\mathrm{CO}_{2}$ pada minggu ke-2 dan ke-4 semua perlakuan mengalami peningkatan, pada minggu ke-6 pemeliharaan kembali mengalami penurunan, dan pada minggu ke-8 hingga minggu akhir CO2 bebas pada semua perlakuan mengalami peningkatan (14-18 ppm) $(p>0,05)$

Nilai alkalinitas selama penelitian mengalami nilai yang fluktuatif pada semua perlakuan dalam setiap pengamatan. Namun demikian nilai rerata tidak menunjukkan perbedaan yang signifikan ( $p>0,05$ ) berkisar 166-168 ppm.

Pengukuran nilai amonia dilakukan di awal, pertengahan dan di akhir penelitian, yang hasilnya dapat dilihat pada Gambar 1.

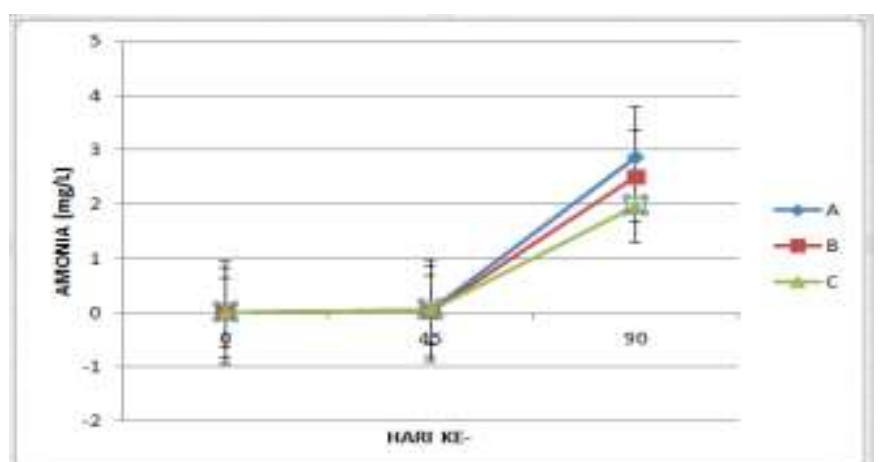

Gambar 1. Nilai analisis amonia perlakuan kontrol (A), aerasi konvensional (B) dan aerasi microbubble (C) selama penelitian

Pengaruh aerator terhadap ammonia (gb.1) selama penelitian menunjukkan bahwa mulai pertengahan penelitian, kandungan ammonia pada semua perlakuan mengalami peningkatan, namun perlakuan aerasi microbubble lebih rendah dari perlakuan lainnya. Rata-rata nilai ammonia samapai akhir penelitian pada kontrol dan aerasi blower melebihi 
2 ppm, sedangkan aerasi microbubble lebih rendah yaitu 1,9 ppm, namun semuanya tidak berbeda nyata $(p>0,05)$.

\section{Performa Ikan}

Hasil penelitian performa ikan selama penelitian dapat dilihat dalam Tabel 3. Hasil penelitian menunjukkan bahwa pada perlakuan aerasi nilai pertumbuhan mutlak (4,02 dan $5,45 \mathrm{~kg})$ dan SR $(88,00$ dan $89,33 \%)$ menunjukkan nilai yang lebih besar $(p<0,05)$ daripada kontrol yang pertumbuhannya hanya 0,97 dan SR-nya 65,33\%, dan perlakuan aerasi microbubble nilai pertumbuhan mutlak dan SR lebih tinggi dibandingkan perlakuan pada aerasi konvensional, namun secara statistik tidak berbeda nyata $(p>0,05)$. Nilai biomasaa pada akhir penelitian menunjukkan perbedaan signifikan $(p<0,05)$ lebih besar $32,5 \%$ $(6,15 \mathrm{~kg})$ dari perlakuan aerasi konvensional $(4,64 \mathrm{~kg})$, dan lebih besar $268 \%$ dari kontrol $(1,67 \mathrm{~kg})$. Nilai FCR pada perlakuan aerasi microbubble lebih rendah $(1,18)$ dari FCR perlakuan aerasi konvensional $(1,33)$, namun tidak berbeda nyata $(p>0,05)$, sedangkan FCR kontrol $(4,42)$ lebih tinggi dari FCR pada perlakuan kedua jenis aerasi $(p<0,05)$.

Tabel 3. Performa ikan selama penelitian

\begin{tabular}{lcccc}
\hline Perlakuan & Pertumbuhan mutlak $(\mathrm{kg})$ & Biomasa $(\mathrm{kg})$ & $\mathrm{FCR}$ & $\mathrm{SR}(\%)$ \\
\hline $\mathrm{A}$ & $0,97 \pm 0,28^{\mathrm{a}}$ & $1,67 \pm 0,30^{\mathrm{a}}$ & $3,42 \pm 1,31^{\mathrm{a}}$ & $65,33 \pm 11,72^{\mathrm{a}}$ \\
$\mathrm{B}$ & $4,02 \pm 0,85^{\mathrm{b}}$ & $4,64 \pm 0,91^{\mathrm{b}}$ & $1,33 \pm 0,11^{\mathrm{b}}$ & $88,00 \pm 6,00^{\mathrm{b}}$ \\
$\mathrm{C}$ & $5,45 \pm 0,01^{\mathrm{b}}$ & $6,15 \pm 0,87^{\mathrm{c}}$ & $1,18 \pm 0,09^{\mathrm{b}}$ & $89,33 \pm 6,11^{\mathrm{b}}$ \\
\hline Keterangan & \multicolumn{4}{c}{ Rerata pada kolom yang sama diikuti oleh huruf yang berbeda menunjukan beda } \\
& nyata pada tingkat kepercayaan $95 \%$ & \multicolumn{4}{c}{}
\end{tabular}

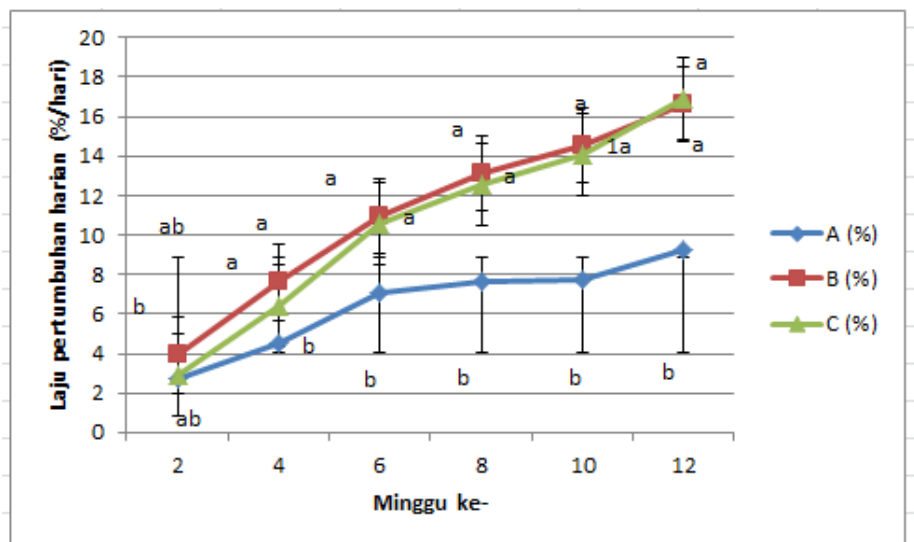

Gambar 2. Laju pertumbuhan spesifik ikan selama penelitian

Nilai laju pertumbuhan spesifik disajikan pada gambar 2. Laju pertumbuhan spesifik menunjukkan tidak ada perbedaan antara perlakuan kedua aerasi $(p>0,05)$, namun keduanya berbeda dengan kontrol $(p<0,05)$. Selanjutnya pengaruh aerasi pada bobot individu menunjukkan nilai yang berbeda nyata antar semua perlakuan pada akhir penelitian (gb. 3) 


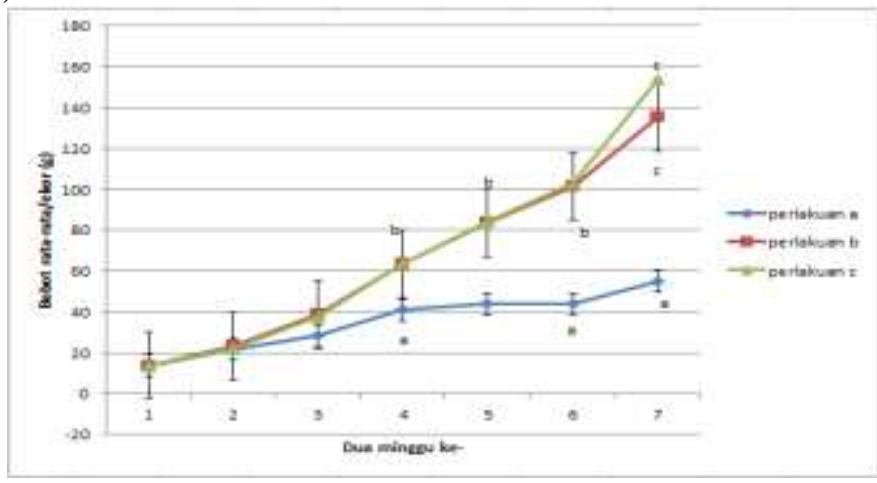

Gambar 3. Bobot rata-rata individu ikan selama penelitian

Hubungan panjang-bobot ikan pada akhir penelitian disajikan pada gambar 4 . Gambar 4 menunjukkan grafik hubungan panjang bobot ikan pada semua perlakuan, dan digunakan untuk mengetahui nilai a dan b yang selanjutnya untuk mengukur faktor kondisi yang disajikan dalam Tabel 4.

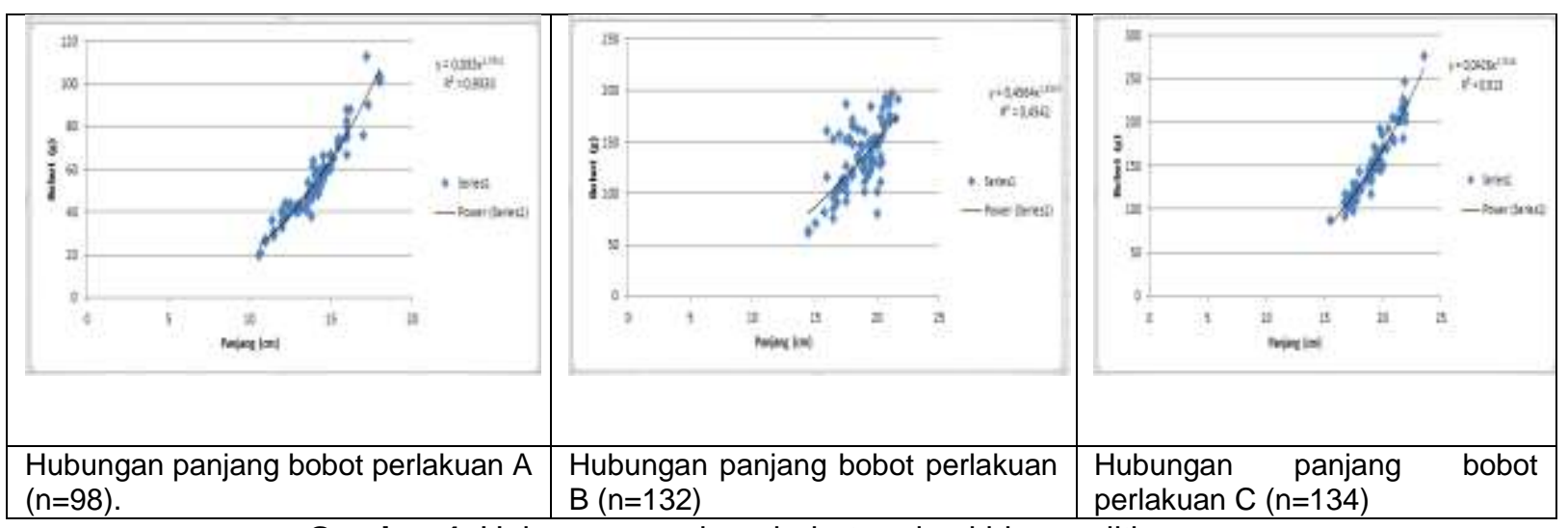

Gambar 4. Hubungan panjang-bobot pada akhir penelitian

Tabel 4. Nilai faktor kondisi (K) dan NVC akhir penelitian

\begin{tabular}{lcccccc}
\hline Perlakuan & nilai a & nilai b & panjang rata-rata $(\mathrm{cm})$ & Bobot rata-rata $(\mathrm{g})$ & nilai K & nilai NVC \\
\hline A & 0,033 & 2,795 & 14,19 & 58,23 & 1,06 & 2,00 \\
B & 0,456 & 1,935 & 18,86 & 139,25 & 1,04 & 2,07 \\
C & 0,043 & 2,762 & 19,19 & 151,59 & 1,02 & 2,15 \\
\hline
\end{tabular}

Pada penelitian ini semua perlakuan mempunyai nilai b kurang dari $3(b<3)$ yang disebut allometrik negatif (tabel 4). Nilai faktor kondisi (K) antar perlakuan relative sama berkisar 1,02-1,06, demikian juga dengan nilai NVC yang berisar 2,00-2,15.

\section{Analisis Kualitas Air}

Oksigen terlarut merupakan salah satu parameter kualitas air yang sangat penting dalam menentukan status mutu perairan, sehingga penggunaan jenis aerator akan sangat menentukan keberhasilan dalam meningkatkan produksi budidaya. Pengaruh aerasi microbubble dalam penelitian ini menunjukkan bahwa oksigen yang dihasilkan menunjukkan nilai yang paling tinggi diatas $3 \operatorname{ppm}(\mathrm{p}<0,05)$ dibandingkan aerator konvensional dibawah 3 ppm dan kontrol dibawah 2 ppm (tabel 2), karena gelembung yang dihasilkan aerator microbubble lebih stabil dan bertahan lama di dalam air sehingga tidak 
mudah berdifusi ke udara seperti pada aerator konvensional. Hal ini sesuai dengan penelitian sebelumnya yang menyatakan bahwa aerator microbubble dapat meningkatkan jumlah oksigen terlarut dalam air karena gelembung udara yang dihasilkan lebih kecil daripada ukuran gelembung yang diproduksi dari aerator biasa (Deendarlianto, et al., 2015), dikatakan juga bahwa gelembung pada aerator konvensional yang ukurannya lebih besar cenderung lebih cepat berdifusi ke udara dan tidak merata masuk ke dalam badan air, berbeda dengan gelembung pada aerator microbubble yang berukuran mikro dapat bertahan dengan periode yang lebih lama di dalam air, sehingga proses difusi ke dalam perairan menjadi lebih baik (Deendarlianto et al., 2015).

Parameter kualitas air yang memengaruhi DO adalah suhu. Semakin tinggi suhu air, kelarutan oksigen semakin kecil. Dalam penelitian ini nilai suhu cenderung berfluktuatif (tabel 2), namun perlakuan kontrol tidak berbeda nyata dengan perlakuan aerator konvensional, tetapi berbeda nyata dengan suhu air pada perlakuan erasi microbubble $(p<0,05)$. Namun demikian secara umum hasil dari nilai rerata pada masing-masing perlakuan menunjukkan bahwa suhu air masih dalam kisaran standar untuk kehidupan nila yaitu $26-29^{\circ} \mathrm{C}$, dimana menurut SNI (2009) suhu standar budidaya nila berkisar $25-32^{\circ} \mathrm{C}$, dan menurut Mjoun dan Kurt (2010), suhu optimal bagi pertumbuhan ikan nila berkisar pada 22-29 ${ }^{\circ} \mathrm{C}$. Tingginya suhu pada perlakuaan aerasi microbubble karena terjadinya gesekan mekanis antara partikel air dengan filter aerasi microbubble dan dinding bak pemeliharaan akibat adanya semburan partikel udara berukuran mikro yang menyebabkan kondisi perairannya memiliki suhu yang lebih tinggi.

Kandungan $\mathrm{CO}_{2}$ bebas pada semua perlakuan sama-sama menunjukkan nilai yang relatif tinggi ( $p>0.05$ ) dan mencapai nilai 14-18 ppm (tabel 2), artinya perlakuan aerasi pada penelitian ini tidak memberi pengaruh terhadap $\mathrm{CO}_{2}$ bebas di perairan. Nilai $\mathrm{CO}_{2}$ yang cukup tinggi ini sudah melebihi nilai standar yang diijinkan dalam pemeliharaan nila, yang batas maksimumnya adalah 11 ppm menurut Sunarso (2008). Namun menurut Boyd dan Lichkoppler (1979), sebagian besar ikan mampu hidup dalam air dengan kadar $\mathrm{CO}_{2}$ bebas sampai 60 ppm dengan syarat kadar oksigennya harus tinggi.

Nilai pH selama penelitian mengalami fluktuatif (tabel 2), namun perlakuan antar aerasi menunjukkan nilai yang tidak berbeda nyata $(p>0,05)$, dan keduanya berbeda nyata dengan kontrol $(\mathrm{p}<0,05)$, dimana nilai $\mathrm{pH}$ kontrol lebih tinggi. Namun demikian kisaran nilai $\mathrm{pH}$ dalam semua perlakuan masih dalam standar normal yaitu antara 7,3-8,4, yang menurut SNI, nila masih dapat hidup dengan baik pada $\mathrm{pH}$ 6,5-8,5.

Nilai alkalinitas selama penelitian mengalami nilai yang fluktuatif pada semua perlakuan dalam setiap pengamatan. Namun demikian nilai rerata semua perlakuan berkisar 166-168 ppm tidak menunjukkan perbedaan yang signifikan $(p>0,05)$, artinya 
aerasi dalam penelitian ini tidak memengaruhi nilai alkalinitas perlakuan. Alkalinitas menjadi salah satu indikator baik buruknya suatu perairan. Ghufran \& Khurniawan (2007), menyatakan bahwa nilai alkalinitas yang optimum pada perairan untuk budidaya ikan adalah berkisar antara 20-300 ppm. Hasil yang didapatkan pada semua perlakuan memiliki nilai yang optimum karena berada pada kisaran tersebut.

Pengaruh aerator terhadap ammonia selama penelitian (gb. 1) menunjukkan bahwa mulai pertengahan penelitian, kandungan ammonia pada semua perlakuan mengalami peningkatan, namun perlakuan aerasi microbubble lebih rendah dari perlakuan lainnya. Rata-rata nilai ammonia sampai akhir penelitian pada kontrol dan aerasi blower melebihi 2 ppm, sedangkan aerator microbubble lebih rendah yaitu 1,9 ppm. Dari nilai yang didapat menunjukkan bahwa aerator microbubble mampu mereduksi kandungan amonia bebas lebih baik karena menghasilkan kandungan amonia bebas yang lebih rendah diantara semua perlakuan. Namun demikian semua perlakuan melebihi persyaratan hidup nila menurut SNI yaitu <0,02 ppm, namun menurut Boyd (1982), nilai optimum amonia untuk pertumbuhan ikan budidaya yaitu $<0,1 \mathrm{ppm}$, akan tetapi pada kisaran 0-2,4 mg/L masih dapat ditoleransi oleh ikan budidaya. Kandungan oksigen yang meningkat membantu mempercepat proses dekomposisi dan dapat menurunkan kandungan $\mathrm{NH}_{3}$. Hal ini sesuai dengan nilai $\mathrm{NH}_{3}$ pada penelitian ini (gb.3) dari grafik terlihat bahwa nilai ammonia pada akhir penelitian pada perlakuan aerasi microbubble lebih rendah karena oksigen pada perlakuan ini nilainya masih cukup tinggi dibandingkan perlakuan aerasi konvensional dan perlakuan kontrol.

\section{Analisis Performa Ikan}

Pengaruh aerasi terhadap performa selama penelitian menunjukkan bahwa pada pertumbuhan mutlak dan SR perlakuan kedua aerator menunjukkan nilai yang lebih besar daripada kontrol $(p<0,05)$ yang hanya mendapatkan pasokan oksigen dari sistem resirkulasi. Pada perlakuan menggunakan aerasi microbubble laju pertumbuhan spesifik (gb. 2), nilai pertumbuhan mutlak, dan SR (tabel 2) lebih tinggi dibandingkan perlakuan aerasi konvensional, namun secara statistik tidak berbeda nyata $(p>0,05)$. Hal ini berbeda dengan hasil penghitungan biomasaa (tabel 2) pada akhir penelitian yang menunjukkan perbedaan signifikan $(p<0,05)$ bahwa perlakuan aearsi microbubble lebih besar dari perlakuan lainnya, dan perlakuan aerasi konvensional lebih besar dari perlakuan kontrol. Dari hasil penelitian ini menunjukkan bahwa oksigen yang stabil dari arator microbubble menyebabkan pertumbuhan ikan lebih tinggi, karena oksigen terlarut dibutuhkan oleh semua jasad hidup untuk pernapasan, proses metabolisme atau pertukaran zat yang kemudian menghasilkan energi untuk pertumbuhan (Boyd, 1982). Artinya perlakuan aerasi microbubble mampu meningkatkan pertumbuhan ikan dibandingkan aerasi konvensional. 
Bahkan perbedaan ukuran bobot nila yang dihasilkan dengan penggunaan aerasi microbubble menunjukkan perbedaan yang signifikan pada akhir penelitian $(p<0,05)$, seperti yang dijelaskan pada gambar 3 yang terlihat bahwa rata-rata bobot ikan dengan aerasi dan tanpa aerasi memperlihatkan perbedaan yang nyata, walaupun perbedaan pada perlakuan aerasi, baru terlihat ketika bobot ikan mencapai $100 \mathrm{~g}$. Hal ini sesuai pendapat Lakani (2013), yang mengatakan bahwa pertumbuhan ikan di awal massa pertumbuhan cenderung sama baik pada kondisi oksigen rendah, normal ataupun tinggi. Peningkatan bobot tersebut mencapai $160 \%$ dibandingkan kontrol dan meningkat $9 \%$ dibandingkan dengan perlakuan aerasi konvensional. Sementara biomasa pada perlakuan menggunakan aerasi microbubble meningkat $268 \%$ dari kontrol dan 32,5\% lebih tinggi dibandingkan pada perlakuan aerasi konvensional. Budhijanto et al. (2017) juga menggunakan aerasi microbubble pada budidaya nila, dimana hasilnya dapat mempercepat proses degradasi bahan organik, dan dapat meningkatkan pertumbuhan.

Perlakuan aerasi microbubble juga memberikan nilai yang bagus pada nilai FCR yang lebih rendah daripada perlakuan aerasi konvensional, meskipun keduanya tidak berbeda nyata $(p>0,05)$, namun berbeda nyata dengan kontrol $(p<0,05)$ (tabel 3$)$. Hal ini menunjukkan bahwa perlakuan aerasi microbubble mampu menghasilkan nilai FCR yang rendah, sehingga pakan yang diberikan lebih efisien digunakan oleh ikan untuk pertumbuhan, terbukti dengan biomasa yang tinggi pada saat akhir penelitian. Konsentrasi DO yang relatif stabil pada perlakuan aerasi microbubble sampai pada akhir penelitian yaitu 3,25 ppm berpengaruh pada nafsu makan ikan, metabolisme dan pertumbuhan. Hal ini sesuai dengan persyaratan nilai DO standar untuk budidaya nila untuk tetap mengalami pertumbuhan, yaitu $>3$ ppm (SNI, 2009). Beberapa penelitian juga melaporkan bahwa gelembung mikro mampu meningkatkan pertumbuhan pada budidaya ikan (Onari et al., 2002; Wiratni et al., 2017; Saputra et al., 2018) dan dengan pertumbuhan yang baik juga berpengaruh dengan tingkat kelulushidupan ikan (SR), dimana SR dari perlakuan aerasi lebih besar dibandingkan kontrol $(p<0,05)$.

\section{Faktor Kondisi dan nilai NVC}

Pada penelitian ini semua perlakuan mempunyai nilai b kurang dari 3 (tabel 4.), yang disebut allometrik negatif artinya semua perlakuan menunjukkan bahwa pertambahan panjang lebih cepat dibandingkan pertambahan bobot. Hal ini terjadi karena ukuran ikan yang ditebar saat perlakuan masih berukuran kecil, yaitu rata-rata $12 \pm 3 \mathrm{~g}$ sehingga pertumbuhan panjangnya lebih cepat daripada bobotnya. Hal ini dibuktikan dengan perbedaan bobot pada perlakuan aerasi, baru terlihat pada akhir penelitian (gb. 3). Hal ini sesuai juga dengan penelitian Ibrahim et al. (2017) yang menganalisa ikan selar kuning pada ukuran ikan yang masih kecil, terjadi pertumbuhan allometrik negative. Menurut 
Effendie (2002), pengaruh ukuran panjang dan bobot tubuh ikan sangat besar terhadap nilai $b$ yang diperoleh sehingga secara tidak langsung faktor-faktor yang berpengaruh terhadap ukuran tubuh ikan akan mempengaruhi pola variasi dari nilai b. Pada penelitian ini semua perlakuan menunjukkan nilai faktor kondisi yang relatif sama yaitu rata-rata 1. Hal ini karena hasil analisa panjang-bobot ikan pada semua perlakuan menunjukkan relatif sama, meskipun dari hasil performa menunjukkan bahwa perlakuan aerasi berbeda nyata dengan non aerasi. Artinya tidak ada pengaruh aerasi terhadap faktor kondisi ikan. Menurut Okgermen (2005), kajian hubungan panjang berat penting diketahui karena dengan adanya informasi ini dapat diketahui pola pertumbuhan, informasi mengenai lingkungan dimana spesies tersebut hidup dan tingkat kesehatan ikan secara umum. Menurut Frose dan Torres (2006) nilai faktor kondisi dapat menggambarkan keadaan fisiologis dan morfologis spesies. Nilai faktor kondisi yang relatif sama dalam penelitian ini menunjukkan bahwa semua kondisi media perlakuan di akhir penelitian masih menunjang untuk kehidupan ikan, meskipun ukuran individu ikan pada kontrol jauh lebih kecil dari ukuran perlakuan aerasi, tetapi karena jumlah ikan lebih sedikit karena terjadi kematian cukup tinggi, sehingga kualitas air yang ada masih mencukupi untuk kebutuhan hidup ikan.

\section{NVC}

Tujuan penelitian menghitung status NVC adalah untuk mengetahui kualitas perairan berdasarkan perlakuan jenis aerasi yang digunakan. Menurut Hadisusanto \& Setyaningrum (2010) Nilai NVC > 1,7 berarti ikan dalam kondisi sehat, dan apabila nilai NVC $<1,7$ berarti kualitas perairan tidak layak untuk media hidup ikan. Nilai NVC pada akhir penelitian menunjukkan nilai yang relatif sama antar perlakuan yaitu rata-rata 2,00-2,15. Hal ini menunjukkan bahwa perlakuan aerasi tidak berpengaruh terhadap status NVC ikan. Artinya status kesehatan ikan dalam semua perlakuan dalam kondisi sehat, meskipun pertumbuhan pada perlakuan kontrol jauh lebih rendah (gr. 3) dan berbeda nyata dengan perlakuan aerasi $(p<0,05)$. Hal ini disebabkan nila adalah ikan yang mudah beradaptasi dan menerima toleransi pada perbedaan kualitas air yang tinggi maupun rendah, sementara kualitas air yang teramati dalam penelitian ini masih dapat ditolerir oleh nila, seperti keadaan oksigen rendah dan ammonia yang tinggi. Hal ini seperti yang diungkapkan oleh Chervinski, (1982), bahwa ikan nila toleran terhadap berbagai kondisi lingkungan, termasuk kadar oksigen terlarut yang rendah (1 ppm); kadar ammonia yang tinggi (2,4 hingga 3,4 mg / L tergabung), dan akan tumbuh dalam air mulai dari asam ( $\mathrm{pH} 5)$ hingga alkali $(\mathrm{pH} 11)$.

\section{$4 \quad$ Kesimpulan dan Saran}

Penelitian ini menunjukkan bahwa aerator microbubble mampu meningkatkan kandungan oksigen dan menyebabkan DO lebih stabil dibandingkan aerator konvensional. Aerator microbubble mampu menaikkan ukuran bobot individu ikan lebih besar $9 \%$ dari 
perlakuan aerator konvensional, dan meningkatkan 32\% biomasa dibandingkan dari perlakuan aerasi konvensional. Aerasi pada penelitian ini terbukti tidak memengaruhi nilai faktor kondisi (K) dan nilai status NVC ikan. Ikan nila yang digunakan dalam penelitian ini merupakan jenis yang memiliki kemampuan adaptasi yang baik, yang mempengaruhi kinerja aerator microbuble. Analisa usaha tani diperlukan untuk melihat seberapa besar efisiensi penggunaan aerator microbubble, terutama dengan melakukan penelitian pada kepadatan yang lebih tinggi.

\section{Daftar Pustaka}

Asma, N., Muchlisin, Z. A., \& Hasri, I. (2016). Pertumbuhan dan kelangsungan hidup benih ikan peres (Osteochilus vittatus) pada ransum harian yang berbeda. Jurnal IImiah Mahasiswa Kelautan Perikanan Unsyiah, 1(1).

Boyd, C. E., and Lichtkoppler, F. (1979). Water Quality Management in Pond Fish Culture. Auburn University. Auburn. Alabama

Boyd, C. E. (1982). Water quality management for pond fish culture. Elsevier Scientific Publishing Co..

Budhijanto, W., Darlianto, D., Pradana, Y. S., \& Hartono, M. (2017, May). Application of micro bubble generator as low cost and high efficient aerator for sustainable fresh water fish farming. In AIP Conference Proceedings (Vol. 1840, No. 1, p. 110008). AIP Publishing LLC.

Chervinski, J. (1982). Environmental physiology of tilapias. In The Biology and Culture of Tilapia. Proceedings ofthe 7th ICLARM Conference, Manila, Philippines: International Center for Livin (pp. 119-128).

Deendarlianto, D., Tontowi, A. E., Indarto, A. G. W. I., \& Iriawan, A. G. W. (2015). The implementation of a developed microbubble generator on the aerobic wastewater treatment. International Journal of Technology, 6(6), 924-930.

Effendie, M.I. (2002). Biologi perikanan. Yogyakarta: Yayasan pustaka nusatama.

Encina, L., \& Granado-Lorencio, C. (1997). Seasonal changes in condition, nutrition, gonad maturation and energy content in barbel, Barbus sclateri, inhabiting a fluctuating river. Environmental Biology of Fishes, 50(1), 75.

FAO. (2018). The State of World Fisheries and Aquaculture 2018-Meeting the sustainable development goals. Licence: CC BY-NC-SA 3.0 IGO.

Frose, R., A. Torres. (2006). Fishes Under Threat An Analysis of The Fishes in the IUCN Red List, p.131-144. R.S.V Pullin, D.M. Bartler and J.Koiman (eds). In Towards Policies for Conservation and Sustaianable Use of Aquatic Genetic Resources. ICLARM conference Proceding 59; 277p

Ghufran, H. M. dan Kurniawan K. (2007). Pengelolaan Kualitas Air dalam Budidaya Perairan. Jakarta: Rineka Cipta.

Hadisusanto, S., \& Setyaningrum, H. M. (2010, September). Status kualitas perairan rawa jombor, klaten, berdasarkan nilai NVC (Nutrition Value Coefficient) ikan. In Prosiding seminar nasional biologi 2010 (pp. 357-371). Fakultas Biologi UGM.

Ibrahim, P.S., I. Setyobudiandi, dan Sulistiono. (2017). Hubungan Panjang Bobot dan Faktor Kondisi Ikan Selar Kuning (Selaroides leptolepis) di Perairan Selat Sunda. Jurnal IImu dan Teknologi Kelautan Tropis, 9(2), 577-584 
ISSN 2354-7251 (print)

KKP (Kementerian Kelautan dan Perikanan). (2019, Februari 19). KKP siapkan program prioritas 2019 untuk perkuat struktur ekonomi pembudidaya ikan. Retrieved from Kementerian Kelautan dan Perikanan - KKP: https://kkp.go.id/djpb/artikel/9003-kkpsiapkan-program-prioritas-2019-untuk-perkuat-struktur-ekonomi-pembudidaya-ikan

Lakani, F. B., Sattari, M., \& Falahatkar, B. (2013). Effect of different oxygen levels on growth performance, stress response and oxygen consumption in two weight groups of great sturgeon Huso huso. Iranian Journal of Fisheries Sciences, 12(3), 533-549.

Lucky, Z. (1977). Methods for the diagnosis of fish diseases. New Delhi: Amerind Publishing.

Matsuo, K. (2001). Study on scallop cultivation by using micro bubble technique. In Proc. Annu. Conf. Jpn Soc. Civil Eng., JSCE, 2001 (Vol. 2, pp. 384-385).

Kamal, M., Kurt, A., \& Michael, L. B. (2010). Tilapia Profile and Economic Importance South Dakota Cooperative Extension Service USDA Doc. Retrieved form: http://pubstorage. sdstate. edu/AgBio_Publications/articles/FS963-01. pdf, 108.

Okgerman, H. (2005). Seasonal Variation of The Lenght Weight and Condition Factor of Rudd (Scardinius erythrophthalamus L) in Spanca Lake.International Journal of Zoological Research. 1(1) : 6-10

Onari, H., Maeda, K., Matsuo, K., Yamahara, Y., Watanabe, K., \& Ishikawa, N. (2002). Effect of micro-bubble technique on oyster cultivation. Proceedings of Hydraulic Engineering, 46, 1163-1168.

Ronald, N., Gladys, B., \& Gasper, E. (2014). The effects of stocking density on the growth and survival of Nile tilapia (Oreochromis niloticus) fry at son fish farm. Uganda. $J$ Aquac Res Dev, 5(2).

Saputra. H.K., Nirmala,K., E.Supriyono, Rochman, N.T. (2018). Micro/Nano Bubble Technology : Characteristics and Implications Biology Performance of Koi Cyprinus carpio in Recirculation Aquaculture System (RAS). Omni-Akuatika, 14 (2): 29 - 36

SNI (Standar Nasional Indonesia). (2009). Produksi Induk Ikan Nila Hitam (Oreochromis niloticus Bleeker) Kelas Induk Pokok. Badan Standarisasi Nasional (BSN). Jakarta.

Sunarso. (2008). Manajemen Kualitas Air. http://pdfWaterEngineer.com/manajemen Kualitas Air 